\title{
NUCLEOLAR ORGANISER REGIONS IN THYROID LESIONS- A STUDY AT A TERTIARY CARE HOSPITAL IN SOUTH INDIA
}

\author{
Sheela Varghese1, Letha Vilasiniamma²
}

${ }^{1}$ Assistant Professor, Department of Pathology, Government Medical College, Kottayam.

${ }^{2}$ Additional Professor, Department of Pathology, Government Medical College, Kottayam.

\section{ABSTRACT}

\section{BACKGROUND}

The sizes and positions of nucleoli and the proportions of their contents can vary with metabolic state, cell cycle phase and the degree of differentiation. Nucleoli aggregate and disaggregate through cell cycle. In interphase, there is complex aggregation of nucleoli (Crocker J, 1989). The principal NOR associated proteins are RNA polymerase1, Nucleolin, Numatrin, topoisomerase1, $100 \mathrm{~K}$ protein, 80K protein, Phosphoprotein PP105 \& PP135. (Crocker J, 1987). Nucleolar organiser region (NOR) associated proteins can be demonstrated by silver colloid method. Present study has been done to evaluate NOR associated proteins in 50 cases of thyroid lesions.

\section{MATERIALS AND METHODS}

Fifty cases of thyroid lesions were selected for the study. These included follicular adenoma, follicular carcinoma, papillary carcinoma, medullary carcinoma, colloid nodule, Hurthle cell Adenoma, hyperplastic (cellular) nodule and anaplastic carcinoma. Formalin fixed paraffin embedded $3 \mu \mathrm{m}$ sections were selected for staining. After staining, all the intranuclear AgNOR dots were counted in 100 cells two times by a single observer at 1000x magnification of oil immersion lens.

\section{RESULTS}

AgNOR proteins appeared as dark brown or black dots in the background of yellow stained nuclei of thyrocytes. The size, distribution and numbers of AgNOR dots in different thyroid lesions showed varied morphology and numbers. The size of AgNOR dots in small lymphocytes were taken as internal standard. There were statistically significant difference in the number of AgNOR dots of benign and malignant tumours (P value, <0.0001)

\section{CONCLUSION}

AgNOR staining is a cheap and simple method which can be carried out in ordinary laboratories. Meticulous care is needed in each step of staining and counting. Advanced automated techniques could be used for meticulous quantification of NOR proteins and more research is needed in this field to apply the technique routinely in thyroid pathology.

\section{KEYWORDS}

AgNOR, Nucleolus, Neoplasm, Thyrocytes, NORs.

HOW TO CITE THIS ARTICLE: Varghese S, Vilasiniamma L. Nucleolar organiser regions in thyroid lesions- A study at a tertiary care hospital in South India. J. Evolution Med. Dent. Sci. 2017;6(72):5137-5141, DOI: 10.14260/Jemds/2017/1116

\section{BACKGROUND}

The AgNOR staining has been extensively studied to find alternative techniques of cell kinetics analysis other than flow cytometry. AgNORs are loops of DNA which contain ribosomal RNA genes, present on short arm of acrocentric chromosomes, 13, 14, 15, 21 and 22.1,2 The AgNOR reaction was described over few decades ago by Good Pasture and Bloom (1975) and by Howel et al (1975). It indicates the rate of protein synthesis and the speed of cell cycle. (D Slowinska-Klencka, 2004). ${ }^{3}$ NORs contain a set of silver stainable acidic proteins which are seen predominantly in the nucleolus. Ultrastructural studies have confirmed the specificity of the argyrophilia for NORs. ${ }^{4}$ John Crocker has visualised three AgNOR staining patterns which are seen in

Financial or Other, Competing Interest: None.

Submission 28-07-2017, Peer Review 24-08-2017,

Acceptance 31-08-2017, Published 07-09-2017.

Corresponding Author:

Dr. Letha Vilasiniamma,

Additional Professor,

Government Medical College,

Kerala.

E-mail: drlethav@gmail.com

DOI: $10.14260 /$ jemds $/ 2017 / 1116$ normal and neoplastic cells. Fully aggregated solitary rounded structure, seen in resting lymphocytes. 2. Intranucleolar NORs which are clearly seen within the nucleolus, seen in proliferating cells. 3. NORs distributed throughout the nucleus, seen in malignant cells. Author advocates counting both intranucleolar and extranucleolar AgNOR dots. ${ }^{5}$

AgNOR protein estimation has been done in histopathology and cytology to assess the proliferative activity of cells. Diagnostic value of AgNORs in thyroid lesions has been studied by few authors. According to Hayam A et al, ${ }^{6}$ quantification of AgNOR \& Ki 67 labelling index could be used as ancillary methods in differentiating thyroid lesions which create problems in diagnosis. The behaviour of NORs is intimately related to mitotic and cell cycle phases. This in turn can be correlated with certain features of cell growth and neoplastic change.

\section{Objectives}

a. Evaluation of cell kinetics by counting silver-stained nucleolar organiser regions in 50 thyroid lesions which included predominantly neoplastic lesions where patient's clinical presentation was as solitary nodule. 
b. To compare the AgNOR counts in benign and malignant lesions.

\section{MATERIALS AND METHODS}

In the present study, 50 histopathologically proven thyroid lesions were selected. Sections which were formalin fixed and paraffin embedded previously were dewaxed in xylene, hydrated through decreasing concentrations of ethanol followed by thorough washing in deionised water for 15-20 minutes. In the present study, the preparation of working solution described Crocker and $\mathrm{Nar}^{1}$ was followed. Staining solution consisted of two components, namely solution A Solution B.

\section{Solution A}

$50 \%$ aqueous silver nitrate ( $5 \mathrm{~g}$ of silver nitrate dissolved in $10 \mathrm{~mL}$ of deionised water).

\section{Solution B}

$4 \%$ weight/volume of gelatin in $1 \%$ formic acid over a water bath. (For preparing 1\% formic acid solution $1 \mathrm{~mL}$ of concentrated (85\%) formic acid was added to $84 \mathrm{~mL}$ of deionised water).

\section{Method of staining}

Solutions A \& B were mixed in the ratio 2:1 volume about 30 minutes before staining and poured over the sections using a pipette; just enough to cover the sections. A cover slip was put over each slide for uniform spreading of the staining solutions. Sections were incubated in a dark chamber for 35 minutes. Silver colloid was then washed off with deionised water for 15-20 minutes. Sections were then dehydrated, put in xylene and mounted in DPX.

\section{Quantification of AgNOR}

Silver stained NORs were counted two different times by a single observer at a magnification of $100 \mathrm{X}$ oil immersion lens. 100 representative nuclei of thyrocytes selected. A mean of 10 different areas of the tumour was chosen, where intact nuclei were present in order to determine uniform quantification throughout the lesion. Quantifications were always performed in well-preserved cells, excluding areas of necrosis, staining artifacts or overlapped cells. Various problems were faced during the attempts of standardising the technique. Important points noted are listed according to their sequence in the reaction.

- Using clean glassware.

- Dissolving gelatin.

- Concentration of gelatin used.

- Time of mixing solution A \& B.

- Importance of immediate layering.

- Critical staining time.

- Use of deionised water for washing sections for 10-15 minutes to remove colloidal silver to minimise background staining.

- Counting procedure.

- Careful focusing is necessary to disclose all NORs.

Working experience has proved that deionised water is superior to double distilled water since it causes minimum background staining. Hence, deionised water has been used throughout the reaction.
The glassware used for each experiment has been thoroughly washed, cleaned and dried before use.

Gelatin was dissolved by heating it in $1 \%$ formic acid in deionised water, over a water bath at $60-70^{\circ} \mathrm{C}$ till all crystals were dissolved.

\section{RESULTS}

AgNOR proteins were seen as dark brown/black dots within the nuclei of thyrocytes. The size of NORs in lymphocytes seen adjacent to the thyrocytes were taken as internal control. In most of the benign lesions, one or two AgNOR dots of medium size corresponding to the nucleoli were seen (Figure 1, 2). In most of the malignant lesions, there were diffuse AgNOR distributions throughout the nucleus (Figure 3, 4 \& 5). In malignant lesions, there was considerable variation in size of NORs within the same nucleus. Among the different variants of papillary carcinomas, tall cell variant even though aggressive clinically, showed lesser number of AgNORs. Follicular variant also showed lesser number of AgNOR dots than conventional papillary carcinoma. Among the benign lesions which are histologically proved, Hurthle cell adenomas showed increased number and size of AgNORs, when compared to the other type of benign lesions. Statistical analysis was done using Statistical Package for Social Sciences (SPSS) software. The mean AgNOR per nucleus, the standard deviation, $t$ test and the $P$ value were analysed using the abovementioned statistical package. The mean values of AgNORs evaluated in different lesions in the present study have been summarised in Table 1 . Among the 28 benign lesions, the mean AgNOR number per nucleus was 2.04 and the standard deviation 1.157. Among the 22 malignant tumours, the mean AgNOR number per nucleus was 7.46 and the standard deviation 3.329. Significance of AgNOR values between benign and malignant lesions were calculated using the ' $\mathrm{t}$ ' test. The $\mathrm{T}$ value was found to be -8.033; mean difference 5.417; degree of differentiation 48. The $\mathrm{p}$ value was found to be $<0.0001$ and the levels are found to be significant.

\begin{tabular}{|c|c|c|}
\hline Type of Lesion & Mean & S.D. \\
\hline 1 & 1.914 & 0.407 \\
\hline 2 & 1.16 & 0.167 \\
\hline 3 & 4.27 & 1.59 \\
\hline 4 & 1.52 & 0.46 \\
\hline 5 & 7.65 & 3.18 \\
\hline 6 & 5.03 & 0.251 \\
\hline 7 & 7.5 & 1.29 \\
\hline 8 & 12 & \\
\hline \multicolumn{3}{|c|}{ Table 1. Mean AgNOR Scores in Different Lesions } \\
in Present Study \\
\hline
\end{tabular}

1-Follicular Adenoma; 2. Colloid Nodule; 3. Hurthle Cell Adenoma; 4. Cellular (Hyperplastic Nodule); 5. Papillary Carcinoma; 6. Follicular Carcinoma; 7. Medullary Carcinoma; 8. Anaplastic Carcinoma.

\begin{tabular}{|c|c|c|}
\hline Type & Mean & S.D. \\
\hline Benign & 2.04 & 1.157 \\
\hline Malignant & 7.46 & 3.329 \\
\hline \multicolumn{3}{|c|}{ Table 2. Mean AgNOR Scores and Standard Deviation } \\
(SD) in Benign and Malignant Lesions \\
\hline
\end{tabular}

Mean Difference $=-5.417 ; \mathrm{T}$ Value $=-8.033 ; \mathrm{P}$ Value $=<$ 0.0001 . Degree of Differentiation $=48$. 


\begin{tabular}{|c|c|c|}
\hline No. & Author & Observations \\
\hline 1 & $\begin{array}{c}\text { Khan EM } \\
\text { Pandey R[15] }\end{array}$ & $\begin{array}{c}\text { Total AgNOR number showed overlap } \\
\text { between various lesions and also } \\
\text { showed a wide range of counts in } \\
\text { adenomatous goitre }\end{array}$ \\
\hline 2 & Solymosi T[16] & $\begin{array}{l}\text { Mean AgNOR count significantly } \\
\text { higher in malignant lesions, but } \\
\text { considerable overlap seen }\end{array}$ \\
\hline 3 & Musiaton & $\begin{array}{r}\text { Overlapping of } \mathrm{v} \\
\text { follicular adenomas }\end{array}$ \\
\hline 4 & $\begin{array}{l}\text { Saritha Asostra et } \\
\text { al[18] }\end{array}$ & $\begin{array}{c}\text { Statistically significant difference } \\
\text { between benign and malignant } \\
\text { neoplasms, } \mathrm{p}<0.01\end{array}$ \\
\hline 5 & F HashmiM D[14] & $\begin{array}{l}\text { Counts in adenomas and carcinomas } \\
\text { showed overlap but higher when } \\
\text { compared to normal thyroid. }\end{array}$ \\
\hline 6 & E R Narin et al[19] & $\begin{array}{c}\text { Overlap between carcinomas \& colloid } \\
\text { goitre }\end{array}$ \\
\hline 7 & $\begin{array}{c}\text { Mohammad } \\
\text { Ismail, Hossain et } \\
\text { al[20] }\end{array}$ & $\begin{array}{l}\text { Useful for differentiating benign and } \\
\text { malignant lesions }\end{array}$ \\
\hline 8 & Present study & $\begin{array}{c}\text { Significantly high values in malignant } \\
\text { tumours. }\end{array}$ \\
\hline \multicolumn{3}{|c|}{$\begin{array}{c}\text { Table 3. Few Observations of AgNOR Studies in } \\
\text { Published Reports }\end{array}$} \\
\hline
\end{tabular}

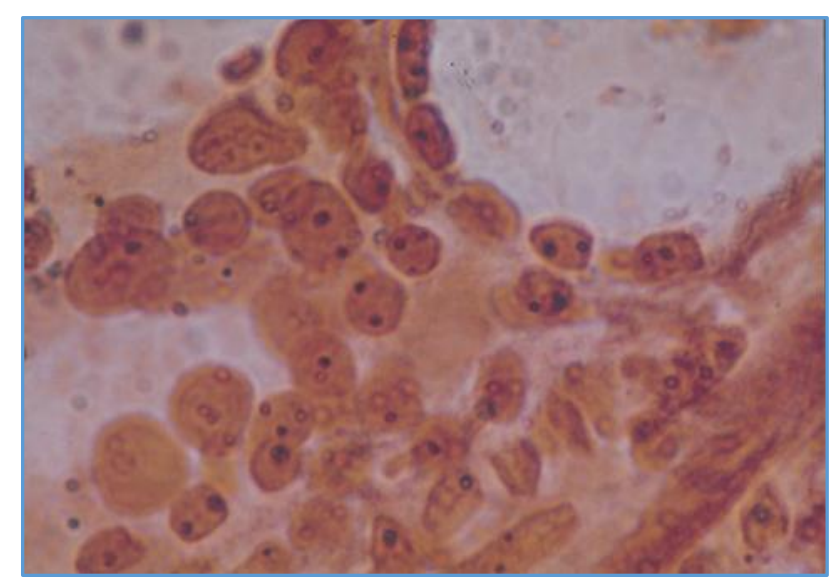

Figure 1. Colloid Nodule Showing 1-2 Discrete AgNORs per Nucleus (1000x)

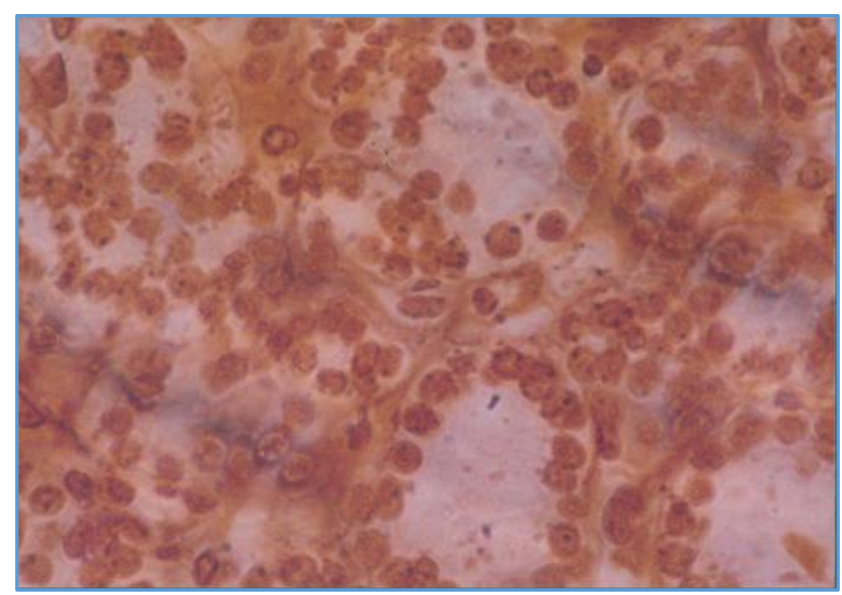

Figure 2. Toxic Nodule Showing Single NOR per Nucleus (400x)

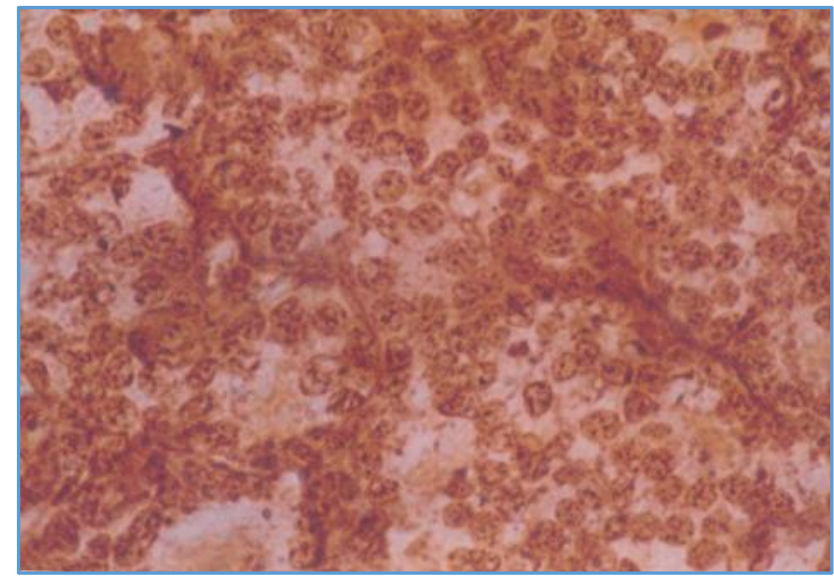

Figure 3. Follicular Carcinoma with Multiple AgNORs (400x)

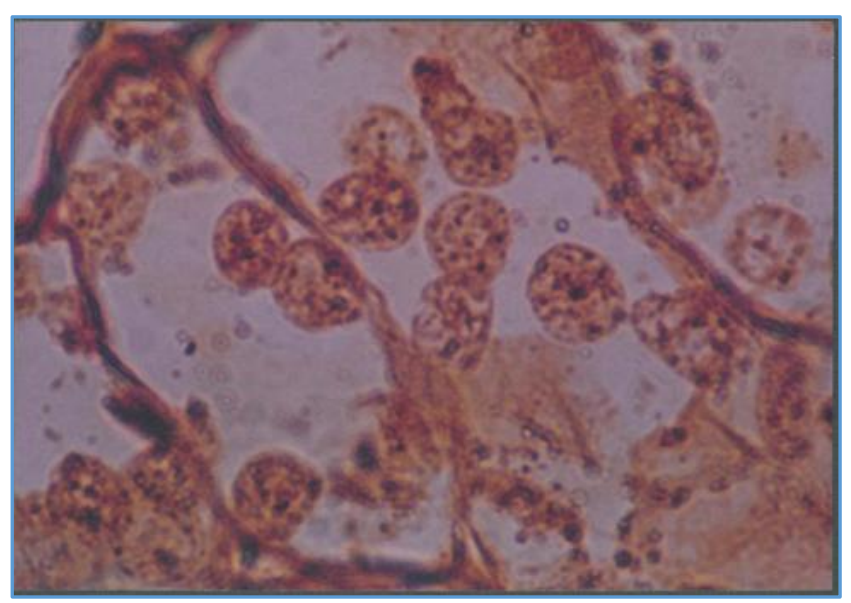

Figure 4. Papillary Carcinoma Showing Numerous AgNORs in Many Nuclei (1000x)

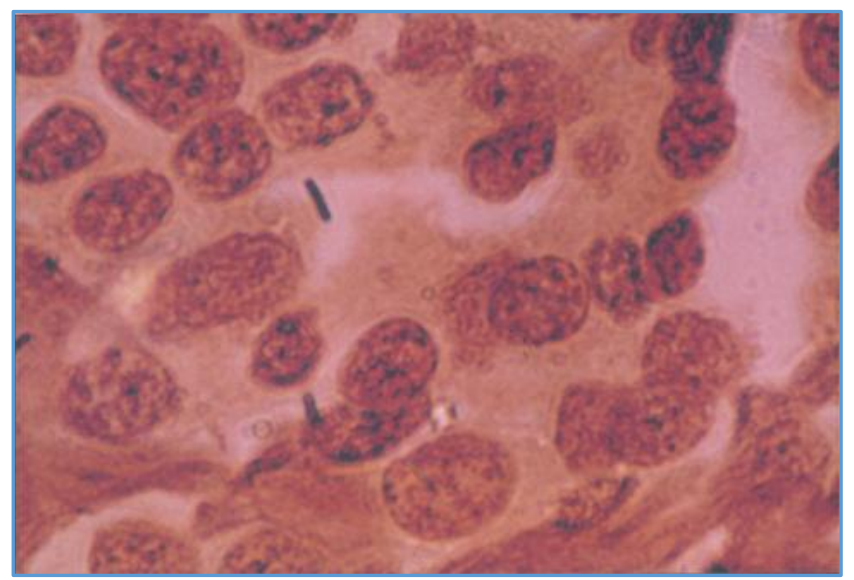

Figure 5. Hurthle Cell Carcinoma Showing Multiple AgNORs (1000x)

\section{DISCUSSION}

The enumeration of silver stained nucleolar organiser regions is regarded as a prognostic indicator in many malignancies. Several studies have been conducted in thyroid lesions both in tissue sections and fine needle aspirations smears.

In the present study, 50 cases were selected which included both benign and malignant lesions. Formalin fixed paraffin embedded $3 \mu \mathrm{m}$ thin sections were used. Ideal 
thickness of $3 \mu \mathrm{m}$ had been proposed by John Crocker et al ${ }^{5}$ to get almost all the NOR profiles. Representative sections of histopathologically proven cases were selected. For each case, 2 sections were stained in order to get accurate results by counting clearly stained intact cells. The effect of a variety of fixatives on tissue biopsy specimens meant for AgNOR staining was studied in detail by Paul. J Smith et al (1988) ${ }^{7}$. They had found that alcohol based fixatives are good enough to give optimum results.

The slides were stained at batches of 25 each at a time. Radhakrishnan et $\mathrm{al}^{8}$ advocates staining of batches of 10-20 slides at a time so that the slides can be examined within two days to prevent the diffuse brown staining of all the structures with passage of time. The staining solution consisted of $4 \%$ gelatin in $1 \%$ formic acid and $50 \%$ aqueous silver nitrate in a 1:2 proportion. The classical staining method adopted by Croker was followed in the present study.

Ploton et al (1986) had modified the original procedure to enable the reaction to occur at a lower temperature $\left(20^{\circ} \mathrm{C}\right)$. A few studies have adopted higher temperatures for incubation. Orell et $\mathrm{al}^{9}$ tried incubation at $45^{\circ} \mathrm{C}$. In the present study, slides were incubated at room temperature.

Varying options exist regarding the time needed for staining. Factors like type of the pathological specimen, type of fixative, thickness of tissue sections, quality of the reagents etc. may influence the staining time and quality (Ruschoff et al). ${ }^{10}$ In different studies incubation times ranging from 14-60 minutes have been tried.10,11, In the present study, incubation has been done for 35 minutes and good results have been seen. It has been found that a slight increase in the staining time was not influencing the intensity of staining, but with prolonged incubations there were diminished resolution of the dots. There was increased chance of background staining as well. Suboptimal staining was not good; counting proved difficult and errors seen sometimes.

An ongoing reaction of silver colloid over several days has been observed by Radhakrishnan et al $^{12}$ in tissue sections, which resulted in undesirable background staining. But this was not noticeable in the present study and slides remain unaltered for 4 - 5 months. After that minimal fading of the silver colloid was seen. Exact proportion of the constituents of the staining solution and the procedure are important. Meticulous cleaning of the glassware and glass slides is especially important. Fungi, dust particles, etc. may mimic the silver stain making evaluation difficult. In the present study, such a problem was not encountered due to thorough cleaning of glasswares. The use of deionised water has been stressed as an absolute requisite for good staining. Some advocate double distilled water, but present study shows that deionised water is optimum.

Assessment of AgNOR status has been done in different ways in different studies. Generally, a hundred cells are assessed as Crocker did in his original method in 1987.1 Orell et al opined that an observer can produce consistent results by counting as few as 30 cells. In the present study, a total of 100 cells were counted in each case from the two slides available.

Usually the total number of AgNORs are taken into consideration i.e. both intranucleolar and extranucleolar AgNORs are counted. The mean score per cell is found after counting the desired number of cells. Orell et $\mathrm{al}^{9}$ has tried counting both intranucleolar and extranucleolar AgNORs separately, but eventually concluded that counting total AgNORs is a better choice. In the present study, total nuclear AgNORs were counted. A $2-6 \%$ interobserver variation has been reported by Radhakrishnan et al (1993) and higher rates by others. Present study showed $1 \%$ variation between 2 counts done by the same observer at different times. Variations in observation at different occasions by the same person are also reported in the literature. Some published reports have shown the mean AgNOR scores in follicular adenomas as $3.5^{13} \& 1.79 .{ }^{14}$ In follicular carcinomas, the mean score has been found as $4.2 \& 5.13,14$ Present study has shown the mean AgNOR score in follicular adenoma as 1.914 and in follicular carcinoma as 5.03. Sarita Asostra et al has observed the mean AgNOR in papillary carcinoma as $5.08+0.278$, medullary carcinoma $-3.47+0.54$. This has been found to be slightly lower than that in the present study. Considerable overlap of AgNOR scores in different lesions has been observed by few investigators ${ }^{15,16,17,18}$ [Table3]. Another investigator has established statistically significant difference between benign and malignant thyroid lesions and the $\mathrm{P}$ value has been found to be $<0-001 .{ }^{19}$ Still another researcher found it as a useful technique to differentiate the benign \& malignant thyroid lesions. ${ }^{20}$ Analysis of the present study has shown statistically significant differences in AgNOR scores between benign and malignant lesions $(\mathrm{P}<0.0001)$.

\section{CONCLUSION}

The AgNOR staining is a simple, rapid and inexpensive technique which can be performed in any routine laboratory. Counting seems to be cumbersome and time consuming. AgNOR studies in thyroid lesions seems to be correlated with expression of other proliferation markers like PCNA and Ki67 labelling index. In future, more studies in thyroid pathology are needed to establish the role of AgNOR quantification. In the present study, benign thyroid lesions showed less number of AgNORs than malignant tumours and there was statistically significant difference (P value $<0.0001$ ) in AgNOR score between benign and malignant thyroid lesions. Follicular adenoma with capsular invasion showed more AgNORs. Anaplastic carcinoma showed clumped AgNORs which were larger in size also. Automated methods may be employed in future to get high resolution of the NORs and to minimise interobserver variability.

\section{REFERENCES}

[1] Crocker J, Nar P. Nucleolar organizer regions in lymphomas. J Pathology 1987;151(2):111-8.

[2] Underwood JC, Giri DD. Nucleolar organizer regions as diagnostic determinants for malignancy. Journal of pathology 1988;155(2):95-6.

[3] Slowińska-Klencka D, Klencki M, Popowicz B, et al. Multiparameter analysis of AgNOR in thyroid lesions: comparison with PCNA expression. Histol Histopathol 2004;19(3):785-92.

[4] Hernandez-Verdrun D, Hubert J, Bourgeois CA, et al. Ultrastructural localization ofAgNOR stained proteins in the nucleolus during the cell cycle and in other nucleolar structures. Chromosoma 1980;79(3):34962.

[5] Crocker J, Boldy DA, Egan MJ. How should we count AgNORS? Proposals for a standardized approach. Journal of Pathology 1989;158(3):185-8. 
[6] Hayam AA, Bashandy MA, Abdou AG, et al. Significance of AgNOR and Ki67 proliferative markers in differential diagnosis of thyroid lesions. Pathology and oncology research 2013;19(2):167-75.

[7] Smith PJ, Skilbeck N, Harrison A, et al. The effect of series of fixatives on the AgNOR technique. J Pathol 1988;155(2):109-12.

[8] Radhakrishnan VV, Radhakrishnan NS, Rout D, et al. Nucleolar organizer regions in meningiomas. $\mathrm{Br} \mathrm{J}$ Neurosurg 1993;7(4):377-81.

[9] Orrell JM, Evans AT, Grant A. A critical evaluation of AgNOR counting in benign naevi and malignant melanoma. J pathol 1991;163(3):239-44.

[10] Ruschoff J, Contractor H, Plate KH, et al. Evaluation of NORs by automatic image analysis: a contribution to standardization. J Pathol 1990;161(2):113-8.

[11] Sujathan K, Kannan S, Pillai RK, et al. Significance of AgNOR count in differentiating malignant cells from reactive mesothelial cells in serous effusions. Acta Cytologica 1996;40(4)724-8.

[12] Radhakrishnan VV, Radhakrishnan NS, Rout D. Application of silver colloid staining method in the diagnosis of intracranial glioma. Ind J Med Res 1993;98:202-5.

[13] Rüschoff J, Prasser C, Cortez T, et al. Diagnostic value of AgNOR staining in follicular cell neoplasms of the thyroid: comparison of evaluation methods and nucleolar features. Am J Surg Pathol 1993;17(12):1281-8.
[14] Hashemi F, Nasserolesiami P. Comparison of AgNORs in normal thyroid nodular goiter and thyroid neoplasms. Journal of Iran University of Medical Sciences 1999;6(3):246-52.

[15] Khan EM, Pandey R. Differential diagnosis of fine needle aspiration smears of thyroid nodules. Cytologic features and AgNORs. Acta cytol 1996;40(5):959-62.

[16] Solymosi T, Tóth V, Sápi Z, et al. Diagnostic value of AgNOR method in thyroid cytopathology: correlation with morphometric measurements. Diagn Cytopathol 1996;14(2):140-4.

[17] Musiatowicz B, Dziecioł J, Augustynowicz A, et al. Overexpression of nucleolar organizer regions in thyroid follicular tumours. Comparison of the cytological and histopathological examinations. Rucz Akad Med Bialymst 1998;43:186-93.

[18] Asotra S, Sharma J. Role of AgNORs in thyroid lesions on fine needle aspiration cytology smears. J Cytol 2008;25(1):18-22.

[19] Nairn ER, Crocker J, McGovern J. Limited value of AgNOR enumeration in assessment of thyroid neoplasms. J Clin Pathol 1988;41(10):1136.

[20] Hossain MI, Md Hassan Q, Bhattacharjee P, et al. Role of multiparameter analysis of AgNOR in FNA smears of thyroid swellings in differentiating benign and malignant lesions. Pathology research international 2012;2012:7. 